\title{
Parens Patriae as a Basis for Provincial Standing IN JUDICIAL REVIEW OF FEDERAL DECISIONS
}

\author{
WILLIAM R. MACKAY
}

As a general rule, legal action can only be pursued by those who have a right infringed in a court that is able to remedy the infringement. Courts can remedy. breaches of private righs and public rights. Typically: purely public rights can only be asseried in a court by the Atromey General. In a federal system, the role of the Atromey General as the parcms patriae endowed with jurisdiction to assert public or sovereign rights in court on behalf of the nation-state is bifurcated. As such. courts must address the issue of standing when a regional government is relying on public rights to seek judicial review of federal decisions. In the United States, the courts have recognized that states should have special treatment with respect to sianding where they are secking to protect "anosi-sovereign" interests. Quasi-sovereign interests inchude the right of a sfate and its citizens to full and equal participation in the federation. Canadian courts have addressed this form of standing peripherally but not in any great detail. This article will examine the nature of the parens patriae form of standing in a federal system and examine whether this form of standing should be recognized by Canadian couris.
Fn rigle genérale. les poursuites juridiques ne

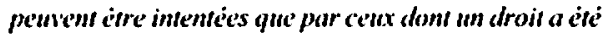
transgressi et anguel an tribunal pent remedier. L's tribunaux pewent remeidier is la transgression de droits prives ef publics. Normalement. tes droiss phblics doivent ètre revendiquis par un procureur genèral devant un tribunal. Dans un système fédéral. te role du procureur géneral. en tant que parens patriac ou père de la patric. defendant les droits publics et étotiques au nom de la nation-Etat, est bifurquée. c'est-à-dirc que les tribumanx doivent aborder la question du droit de comparaitre lorsqu iun gownernement se fie anx droits publics pour demunder

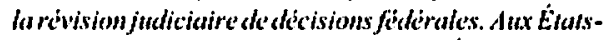
Unis, les tribmanx on recomm ane les Elats devaient obtenir un traitement spicial en ce qui concerne te droit de comparaitre lorsqu its venlem se proteger d'interèts " quasi-èatigues ". Les intérèts quasiefatiques comprennent le droit d'un Etat et de ses citoyens à une participation pleine et égale dans la fideration. Les tribunaux camadiens on aborde cette forme de droit de comporaitrc en margc. sans toutefois trop de delails. L arficle examine la nature du droit de comparaitre duparens patriase dans un systeme fedéral ef si cette forme de compormion de'vrait itre recomme par les rribuman canaticns.

\section{TABLE OF CONTENTS}

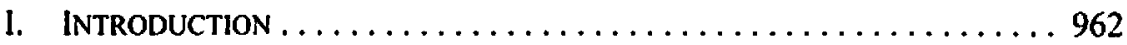

II. A WORD ABOUT STANDING $\ldots \ldots \ldots \ldots \ldots \ldots \ldots \ldots \ldots \ldots \ldots \ldots$

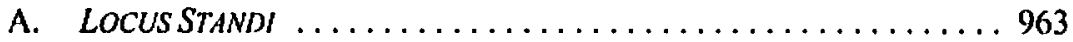

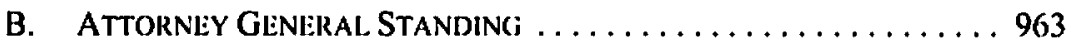

C. The AtTorney Glentiral's Rol.f as Parens Patrial: ....... 964

D. Private Plaintiff's Right to Enforce Public Rights ..... 965

E. Provincial and State Standing;

TO PROTECT QUASI-SOVEREIGN INTERESTS $\ldots \ldots \ldots \ldots \ldots \ldots 96$

III. Standing IN CANAdA ......................... 966

A. Standing to Enforce Public Rights $\ldots \ldots \ldots \ldots \ldots \ldots, 966$

B. Public Interest Standing $\ldots \ldots \ldots \ldots \ldots \ldots \ldots \ldots \ldots 96$

C. Parens Patrial: Standing to Protect Public Rigihts ..... 967

D. Standing for Judicial. Review in Fideral Court . . . . . . 969

Senior Legal Counscl. Government of Nunavut. Department of Executive and Intergovemmental Affairs. I would like to thank Timothy Wild and David Nurse for comments on the draft of this article. The views expressed are thuse of the author. 
E. Provincial Standing to Seek Judicial Review

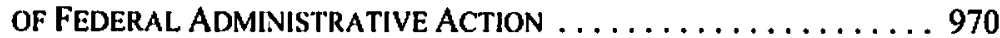

IV. Standing In the United States ..................... 975

A. Standing to Enforce Public Rights $\ldots \ldots \ldots \ldots \ldots \ldots .975$

B. Public Interest StANding ................... 976

C. Parens Patriat: Standing to Protect Public Rights ...... 977

D. StATE Standing to SEek Judicial Review of

FEDERAL AdMINISTRATIVE ACTION $\ldots \ldots \ldots \ldots \ldots \ldots \ldots . \ldots 79$

V. THE PROPler ROLE OF THE PARENS PATRIAE DOCTRINe

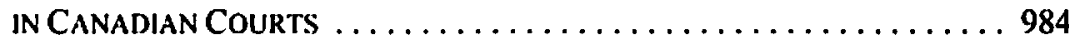

A. The Role of the Courts in a Federal State .......... 984

B. THE SCOPE OF THE CROWN's PARENS PATRIAE StaNdING TO PROTECT QUASI-SOVEREIGN RIGHTS .............. 986

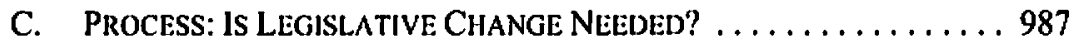

VI. Conclusion $\ldots \ldots \ldots \ldots \ldots \ldots \ldots \ldots \ldots \ldots \ldots \ldots \ldots . \ldots 98$

\section{INTRODUCTION}

The English jurist Sir Edward Coke asserted in 1610 that the courts have original jurisdiction to review legislation and declare it invalid when it "is against common right and reason, or repugnant, or impossible to be performed." While this assertion was not generally accepted in English common law, the tradition of judicial review was more fully aggregated into American law with its written Constitution. The seminal case of Marbury v. Madison (Secretary of State of the United States) ${ }^{2}$ confirmed that the courts are bound to declare null Acts of Congress that conflict with the American Constitution. Accordingly, in a constitutional federation, litigants may seek judicial review of legislation on the grounds that it is in conflict with the division of legislative jurisdiction in the federal Constitution. This basis of judicial review is also accepted by Canadian courts.

Additionally, in both Canada and the United States, petitioners may seek judicial review of a public body on some other non-constitutional ground alleging that the public body acted outside its legislative jurisdiction. However, to seek judicial review, a petitioner must have standing. There must be some sort of discrete effect on the petitioner stemming from the actions of a public body.

This article will focus on the issuc of standing where a province is seeking judicial review of a federal administrative decision. In Canada, while legislation often gives the provinces automatic standing to challenge the validity of legislation which may be outside the federal Parliament's constitutional jurisdiction, a province essentially has the same access to the courts to seek judicial review of federal administrative action as an ordinary member of the public. The article will then examine how American courts address standing when states seek judicial review of federal administrative decisions. Finally, the article will consider whether it is necessary or beneficial for Canadian courts to adopt a similar approach. 


\section{A Word About Standing}

\section{A. LOCUS STANDI}

The focus of this article is a provincial Crown's right to access the courts to protect its quasi-sovereign rights in the face of federal administrative action. Accordingly, the traditional basis for the Attorney General's standing to protect public rights should first be outlined. Second, the heretofore main basis provinces have relied on to gain standing to protect public rights - the court's discretion to grant standing in the public interest should be examined. Additionally, the parameters of the Crown's broader parens patriae right to standing to protect sovereign and quasi-sovereign interests should be delineated.

Locus standi literally translated means a "place of standing." In the legal sense, it means a right of appearance in a court of justice on a given question. ${ }^{3}$ The principle that one must have a legal right infringed or threatened before a private law remedy can be sought from a court has been widely accepted in the common law for centuries. Ubi jus, ibi remedium where there is a right, there is a remedy - is a maxim reproduced in William Blackstone's Commentaries on the Laws of England. ${ }^{\star}$ Simply put, legal action can only be pursued by those who have a legal right infringed in a court that is capable of remedying the infringement.

This is true, however, only with respect to actions between individuals dealing with private rights which give rise to an action within the categories of private law, such as a breach of contract or trust, or the commission of a tort. Conversely, a public right is one that is enjoyed more broadly, suclı as the right to access a highway, for instance. Generally speaking, only the Attorney General has standing to institute proceedings to protect public rights or enforce public law by virtue of his or her capacity as parens patriae. An individual has standing to enforce public rights or laws only where he or she can show there is a discrete harm to him or her caused by a breach of public laws or rights. The main exception to this rule is the court's discretion to grant standing to litigants where it is in the public interest to do so.

\section{B. Attornfy General. Standing}

The Attorney General's right to standing to protect public rights or enforce public laws stems from its duty to protect the Crown's sovereign interests." The Crown's sovereign interest is its interest in seeing that its laws are obeyed and enforced. Accordingly, behaviour that violates the Crown's law is considered a threat to the Crown's sovereignty and it may commence an action to protect its sovereignty. Halsbury's Laws of England notes that "[t]he

Black's Law Dictionany, 8th ed., s.t: "locus standi."

William Blackstone, Commentaries on the Laws of England, vol. 3 (Chicago: University of Chicago Press, 1979) at 23.

, Sec Ilugh H.L. Bellot. "The Origin of the Attomey-General" (1909) 25 Law Q. Rev. 400 at 401, 408409. 
public is concerned to see that Acts of Parliament are obeyed, and the Attorney General represents the public as a whole in insisting that the law be observed."

In Ontario (A.G.) v. Grabarchuk, the Ontario Court of Appeal stated, "[t]here are numerous precedents in England and Australia for the proposition that the Attorney-General, as the protector of public rights and the public interest, may obtain an injunction where the law as contained in a public statute is being flouled."

\section{The atrorney General's Role as Parens Patriaf}

Courts in Canada often cite the Attorney General's right to standing to enforce public legal rights, but remain silent on the broader source of this standing - the role of the Attorney General as parens patriae. The parens patriae action has its roots in the royal prerogative of the Crown to act as guardian for those unable to act for themselves. Courts expanded the doctrine to encompass the government's power to sue in response to injuries to other interests. The Crown's interests can be sovereign, quasi-sovereign, ${ }^{8}$ or proprictary. The Crown's proprietary interests are those that it asserts on its own behalf as a property owner. Proprietary interests are generally not protected by the Crown's role as parens patriae but rather as an ordinary litigant.

The Altorney General in his or her capacity as parens patriae has standing generally to scek an injunction to prevent breaches of the Crown's sovereign rights enunciated by the public law. ${ }^{9}$ The earliest and most familiar illustrations of the Attorney General intervening to protect the public from a wrongful invasion of its common legal rights are actions brought to restrain a public nuisance." This gradually evolved to include standing to seek damages, in addition to an injunction, for public nuisance affecting public rights.

In addition to granting the Attorney General standing to protect sovereign and proprietary rights, American courts also recognize the Attomey General's right as parens patriae to standing to protect "quasi-sovereign" rights such as the health and well-being - physical and economic - of its citizens and territory. Additionally, American courts recognize this standing not just for nuisance claims but for negligence and other torts. The courts have also granted relief in the form of both damages and injunction. Canadian courts have also implicitly recognized this basis of standing and rights to both equitable relief and damages.

Hatsbury's Laws of Englond, 4th ed. reissue, vol. 24 (London: Butterworths, 1991) at 500-501, para. 943 [footnotes omitted].

(1976), 11 O.R. (2d) 607 (H. Cl. J.) at 612; sec also Craig E. Jones, "The Attorncy General's Standing 10 Seck Relief in the Public Interest: The Evolving Doctrine of Parens Paltrate" (2007) 86 Can. Bar Rev. 121.

Allan Kanner, "The Public Trust Doctrine, Parens Patriace, and the Attorncy General as the Guardian of the Stale's Natural Resources" (2005) 16 Duke Envtl L. \& Pol'y F. 57 at 100.

Jones, supra note 7 at 125.

10 Law Reform Commission of British Columbia, Report On Civil Litigation in the Public Imterest (Vancouver: Law Reform Commission of British Columbia. 1980) at 25. 


\section{Private Plaintiff's Right to Enforce Public Rigits}

Traditionally, only the Attorney General has standing to assert a purely public right or interest through court proceedings. However, there are exceptions to the rule. A private plaintiff has standing to sue to protect public rights without the Attorney General being a party if he or she satisfies either of the two conditions laid out in Boyce v. Paddington Borough Council:

A plaintiff can sue without joining the Attorney-(ieneral in two cases: lirst, where the interference with the public right is such that some privale right of his is at the same time interfered with ... and, secondly, where no privale right is interfered with, but the plaintiff, in respect of his public right, suffers special danage peculiar to himself from the interference with the public right. ${ }^{\text {" }}$

Thus, an individual can only be granted standing to enforce a public right where there is interference with a private right or he or she suffers peculiar damage from interference with a public right. This continues to be the general application in both Canada and the U.S.

\section{E. Provincial and State Standing to Protect QUASI-SOVEREIGN INTERESTS}

Canadian and American courts have similar approaches to standing. In order to have standing in court, litigants must be directly and discretely affected by the government decision or, if the petitioner has no standing, it must be in the public interest for the court to hear a case. However, there is one area where the courts in Canada and the U.S. differ. American courts explicitly treat states differently with respect to standing. There is a long history of recognizing a U.S. State's parens patriae standing to use the courts to protect its quasi-sovereign interests. In Canada, this doctrine is not as well-developed.

As noted, the right of the Attorney General to standing in court to protect a sovereign interest is not controversial. For the most part, a sovereign interest is usually easily identifiable and generally consists of the exercise of sovereign power to enforce civil and criminal legal codes. ${ }^{2}$ In both Canada and the U.S., for example, the Crown or state's standing to prosecule criminal offences in court and the sovereign interest upon which that standing is based is unquestioned.

American courts have also specifically recognized a class of quasi-sovereign state interests that can support parens patriae actions. Quasi-sovereign interests are "not sovereign interests. proprietary interests, or private interests pursued by the State as a nominal party. ${ }^{13}$ There are two types of quasi-sovereign interests (but the categories are not closed):

- "[A] State has a quasi-sovereign interest in the health and well-being - both physical and economic - - of its residents in general": ${ }^{1+}$ and 
- $\quad[\mathrm{A}]$ State has a quasi-sovereign interest in not being discriminatorily denied its rightful status within the federal system."'s

Both Canadian and American courts accept the Attorney General's standing to seek an injunction to prevent illegal actions. This common law right to standing stems from the Attorncy General's role as parens patriac. However, this common law right to standing is not limited to the injunction remedy and extends to both sovereign and quasi-sovereign interests. The focus of this article is on the until-recently naseent common law right of provincial Attorncys General to standing to seek prerogative writs, including injunctions, in response to federal administrative decisions affecting quasi-sovereign interests.

\section{Standivg In CaNada}

\section{A. Standing to Enforce Public Rights}

The principle in Paddington was affirmed by the Supreme Court of Canada in MacIlreith v. Harr Estare. ${ }^{16}$ Indeed, this principle - that special and peculiar damage forms the basis for standing - has been treated as an authoritative expression of the law and applied on several occasions in Canada. ${ }^{17}$

\section{B. Public Interest Standing}

In Canada, this general rule has been augmented as courts have recognized their discretion to grant standing in the public interest. This form of standing was addressed in Thorson $v$. Camada (A.G.);'1" Nova Scotia (Bourd of Censors) v. McNeil: ${ }^{14}$ Canada (Minister of Justice) v. Borowski;" and Finlay." These cases establish the general principle that standing will be granted to a public interest group to challenge either the constitutionality of legislation or the lawfulness of an exercise of administrative authority where:

- the applicant demonstrates a genuine interest as a citizen;

- a serious issue is raised; and

- there is no other reasonably eflective manner to bring the issue before the court.

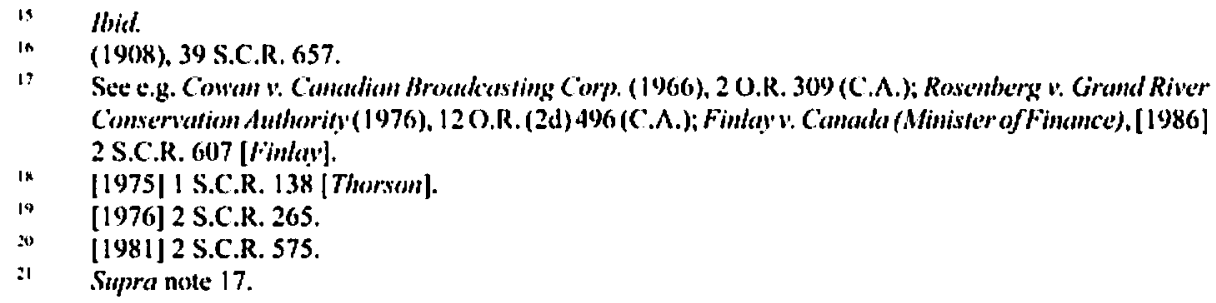




\section{Parens Patriag Standing to Protect Public Rights}

In Canada, the discussion of a province's right to standing based on its role as parens patriae was not extensively addressed until the Supreme Court of Canada's decision in British Columbia v. Canadian Forest Products Lid. ${ }^{22}$ In that case, a fire caused by Canadian Forest Products' controlled burning, caused damage to approximately 1,491 hectares of forest, including areas declared by the British Columbia Crown to be environmentally sensitive to burn. The British Columbia Court of Appeal awarded the Crown compensation for the "diminution of the value" of the non-harvestable trees (in the environmentally protected zone).

This award was the subject matter of Canadian Forest Products' appeal to the Supreme Court of Canada. The Crown sought compensation both as landowner and in a representative capacity for environmental losses suffered by the public generally. In response, Canadian Forest Products argued that such general losses are not recoverable by a landowner in tort. The Supreme Court of Canada acknowledged the authority of the Altorney General to bring suits on behalf of the public for environmental damage stating, "[i]f justice is to be done to the environment, it will oflen fall to the Attorney General, invoking both statutory and common law remedies, to protect the public interest."

The Court further noted that the concept of parens patriae is accepted in the U.S. for both injunctory relief and damages:

\footnotetext{
Under the common law in that country, it has long been accepted that the state has at common law parens parriac jurisdiction to represent the collective interests of the public. This jurisdiction has historically been success fully exercised in relation lo environmental claims involving injunetive relicf against interstatc public nuisances: sce, c.g., Norh Dakotav. Mimesota, 263 U.S. 365 (1923), al p. 374; Missomri v. Mhinois, 180 U.S. 208 (1901): Kansas :. Colorado, 206 U.S. 46 (1907); Georgia v. Tennessee Copper Co., 206 U.S. 230 (1907): and New York v. New Jersey, 256 U.S. 296 (1921). In Tennessee Copper. Holmes J. held for the Supreme Coun of the United States. at p. 237, that, "the Statc has an interest independent of and behind the tilles of its citizens, in all the earth and air within its domain.
}

With respect to the state of the law in Canada, the majority noted that there is no legal barrier to the Crown suing for compensation as well as injunctive relief in response to environmental damage to the public at large. However, the Court was reluctant to address this aspect of the Crown's claim, as "there are clearly important and novel policy questions raised by such actions."2s Specifically, the majority noted:

It is true that the role of the Attorney General has traditionally been to seek a stop to the activity that is inlerfering with the public's rights. This has led to a view that the only remedy available to the Attomey General is injunctive relict. Some commentators regard the injunction as the "public remedy" obtained by the Attomey General. while damages are a "privale remedy" available to those private citizens who have

lid. at para. 78 [cmphasis in original].

Ibid. at para. 81 . 
suffered a special loss such as personal injury or damage to private property: see, c.g., P. H. Osborne, The Law of Torts (2nd ed. 2003), at p. 364.

Canadian courts have not universally adhered to a narrow view of the Crown's available remedies in civil procetedings for public nuisance. In The Queen v: The Ship Sim Diamond. [1984] I F.C. 3 (T.D.). the federal Crown sought damages in relation to cleanup costs it had incurred to mitigate damage from an oil spill in the walers off Vaneouver. Damages were awarded for the cost of the water cleanup activities, in addition lo costs to clean Crown-owned beach and fireshore property. Walsh J. commented, "what was done was reasonable and appears to be a good example of the parens patriac principle with the Crown ... acting as what is referred to in civil law as 'bon pire de famille" "(pp. 31-32). ${ }^{26}$

The Crown did not present evidence at trial as to the valuation of environmental damage. The claim for environmental damage to the province was raised on appeal. Accordingly, the majority proceeded on the basis that the measure of damages was limited to the commercial value of forests which were owned by the Crown and available for commercial use. A new claim for damages for environmental damage to the province generally based on parens patriae was not allowed to proceed. The Supreme Court allowed the appeal and the decision of the trial judge was restored.

In his dissenting reasons, however, LeBel J. disagreed with the majority and found that the province could recover damages for the non-harvestable trees in the environmentally sensitive areas. With respect to the Crown's parens patriac jurisdiction, LeBel J. stated:

My colleague speaks of the impontance of the Crown's parens parriae jurisdiction, and argues that it should not be altenuated by a narrow judicial consiruction (para. 76). Unfonunately, he then goets on to adopt just such a narrow judicial construction by limiting the Crown's entitlement in this particular case to entitlement "in the role the Crown adopted in its statement of claim, namely that of the landowner of a tract of forest" (para. 83). In my view, the fact that the Crown is trying to recover commercial value, or using commercial value as a proxy for the recovery of damages, should not limit the Crown's parens patriac jurisdiction. The Crown, in seeking damages. is still fulfilling its general duty, its parens patriae function to protect the environment and the public's interest in it. I found my colleugue's legal analysis of the Crown's ability to sue in the public interest to be correct, up to the point where he asserts that this ability should somehow be limiled at bar. The Crown's porens parrice jurisdiction allows it to recover damages in the public interest, even to the extent that the Crown adopts commercial value as a proxy lor such damages. I therefore proced on the basis that the Crown's entitlement in this particular case is not limited to the damages that a private landowner might receivc. ${ }^{27}$

It is significant that both the majority and the minority opinions accepted the principle that the Crown may recover damages for harm caused to the Crown not only as a landowner but also in its role as parens patriae. Certainly, the conclusion we can take from Canadian Forest Prodicts is this: Canadian common law recognizes the right of the Crown Attorney General, as parens patriae, to seek equitable relief, as well as damages, from threats not only to the 
Crown's proprietary or sovereign interests, but also threats to the Crown's quasi-sovereign interest in the general well-being of its citizens.

Indeed, with respect to the Supreme Court's decision, Craig E. Jones notes:

Reading the American cases in conjunction with the Supreme Court of Canada's unanimous recognition of parens parriae authority to pursue claims for damages in $C a n f o r$ lcads one to suspect that, just as American courts will allow eluims hased on a threat to the "interest in the health and well-being ... both physical and economic - of its residents in general." the Supreme Court of Canada will uphold a provincial Attorney General's right to sue on a similar basis. At least in cnvironmental claims. but potentially with respect to all the provinces" other "quasi-sovereign" interests as well. 28

Jones notes, “[t]he second category of quasi-sovereign interests described in Snapp is already recognized in Canada; the provinces do not need to rely on judicial interpretations of parens patriae jurisdiction to have standing on questions of federalism."

While provinces do not need to rely on parens patriae standing with respect to questions of the constitutional validity of federal legislation, provincial Attomeys General have the right to standing as parens patriae to seek prerogative writs with respect to federal administrative action for the reasons that follow.

\section{Standing for Judicial Review in Federal. Court}

In 1971, the federal government created the Federal Court of Canada which was granted exclusive original jurisdiction to conduct judicial review of federal boards, commissions, or tribunals. Section 2(1) of the Federal Court $\mathrm{Act}^{30}$ defines these entities as "any body or any person or persons having, exercising or purporting to exercise jurisdiction or powers conferred by or under an Act of Parliament or by or under an order made pursuant to a prerogative of the Crown." ${ }^{31}$ Courts have held that the entities defined by s. 2(1) include Ministers of the Crown. ${ }^{32}$ Standing in the Federal Court is governed principally by s. $18.1(1)$ of the $F C A$ which states:

18.1 (1) An application for judicial review may be made by the Allorney General of Canada or by anyone directly affected by the matter in respect of which relief is sought. ${ }^{33}$

Essentially, the $F C A$ sets out the same test articulated in Paddington regarding who may bring an application for judicial review: the Attorney General, a person whose private rights are interfered with, or a person who suffers special damage peculiar to himself from the

Jones, supra note 7 at 150 [footnoles omitted].

Ibid. at 143 [footnotes omitted]. As noted earlier, the sceond category of quasi-sovereign interest is a state's interest in not being discriminatorily denied its rightlul status within the federal system. See Alfred l. Surapp. supra note 13.

R.S.C. 1985, c. F-7, as am. by S.C. 1990, c. $8[$ FCA $]$.

Jbid.

Maple Lodge Farms Lad. 1. Canada, [1 982] 2 S.C.R. 2 at 6; Canada (A.G.) v. Purcell, [1996] 1 F.C. 644 (C.A.) at para. 31.

FCA, supra note 30, s. 18.1(1). 
interference with the public right. There is little jurisprudence dealing with $\mathbf{s . 1 8 . 1 ( 1 )}$ specifically. However, courts have found that the subsection's wording is broad enough to encompass applicants who are not directly affected when they meet the test for public interest standing. ${ }^{34}$

\section{E. Provincial Standing to Seek Judicial Review OF FEDERAL ADMINISTRATIVE ACTION}

In both American and Canadian courts, a normal litigant must show that he or she is "directly affected" by the decision. ${ }^{35}$ Accordingly, states or provinces in both countries have standing where administrative action affects a proprietary right or sovereign interest held by the state or province.

In the U.S., standing may be granted to a state Attorney General as parens patriae to seek judicial review of federal administrative action if a quasi-sovereign right is affected - a basis for standing not enjoyed by private litigants. In Canada, no court has found that a province has status different from an ordinary litigant when considering the province's standing to petition for judicial review of administrative decisions.

Nonetheless, the rationale for granting Nova Scotia public interest standing in Nova Scotia (A.G.) v. Uliramar Canada is similar to the rationale American courts have used in giving states standing based on quasi-sovereign interests - that is, protecting the well-being of the state and its citizens. In Uliramar, Nova Scotia requested judicial review of written undertakings given by Ultramar to the Director of Investigation and Research appointed under the federal Competition $A c t^{37}$ in connection with that company's purchase, and subsequent operation of, an oil refinery. Ultramar provided a written undertaking to the Director that it would operate the refinery for a period of seven years, barring a change in circumstances, and, if it used its option to close the refinery, it would provide to the Director evidence of its efforts to sell the refinery and that there was no prospective buyer.

Ultramar eventually gave notice of its intent to close the refinery on the basis of material adverse change. Nova Scotia sought an order prohibiting the Director from making a final determination on whether there had been a material adverse change in circumstances. It also sought an order of mandamus to require the Director to act to compel Ultramar to continue the operation of the refinery in accord with the company's written undertakings.

Ultramar and the Director argued Nova Scotia did not have standing to seek judicial relief. The Federal Court summarized the grounds argued for refusing the province standing as: (2003), 227 F.T.R. 96, afrd $2003 \mathrm{FCA} 484,127$ A.C.W.S. (3d) 811, leave to appeal to S.C.C. rclused, 30180 (20) May 2004). 
I. [T] he Province is not "directly affected ..."... |as| the Director's linal conclusion on that the matter has no direct effect on the Province's interests, for only after that determination ... will there be any effect of the Director's decision and action.

2. [T]he Attomey General of the Province, has no role in protection of public interests ... competition in the marketplace... [The concern of the Director] are within the authority [and public interest] of the Attorney General of Canada.

3. [T] he Province is not genuincly interested in the matler ... to be reviewed because [it arises] from federal regulation of competition.... [T]lle Province's principal interest is in maintaining ... employment.

4. [T]he cases dealing with public interest standing concem actions for declaratory relief and they do not readily apply where the [applicant secks] ... prohibition and mandemus orders. ${ }^{38}$

The Court rejected all four of these arguments. It lound that any actions, not just decisions, of the Director were subject to review. It also stated in response to points one and two above that provinces have an interest where federal boards' or regulators' actions affected matters within provincial jurisdiction. ${ }^{39}$ Although a federal action may be within its legislative competence, it may also affect interests arising in other contexts and other legislative responsibilities. Moreover, the Court stated that these interests are potentially sufficient to form a "direct" interest under s. 18.1 of the $F C A{ }^{40}$

The Court then turned to the specific question as to whether the interests raised by the province were sufficient to justify standing. The Court cited Friends of the Island v. Canada (Minister of Public Works)." and stated:

Madame Justice Reed, as we have seen, in Friends of the islond, interpreting subsection 18.1(1), described the judicial discretion in question as tuming upon assessment of the particular circumstances of the case and "the type of interest which the applicant holds", presumably provided that interest is affected by the matter on which judicial revicw is sought. ${ }^{42}$

\section{The Court further stated:}

In my opinion, the Province's interests in competition in the local petroleum marktt and its interests in continued economic activity and employment at the refinery cannot be taken as other than genuine, important public interests which only the Province can represent. These are interests which are affected, in my view. as a result of the activity of the Director in dealing with the issue of material adverse change as raised by Ultramar under the 1990 undertaking. ${ }^{43}$

Uliromar, suprer note 36 at 734-35.

libid.

lbid. at para. 42.

[1993] 2 F.C. 229 (T.D.).

Ultramar, supra note 36 at 737 .

Ibid. at para. 738. 
The Court concluded that the interests of the province were genuine and important and it was "directly affected" by the Director's actions. As such, the circumstances "clearly warrant[ed] recognition of standing for the applicant to seek the relief sought by way of proceedings for judicial review.",4

Although it was not specilically stated, the articulation of the interest affected by the federal government - continued economic activity and employment and competition in the local petroleum market - are quasi-sovereign interests which, in the words of the Court, "only the Province can represent." interest standing but, using the well-developed analysis in the American courts, the Court could have easily characterized the Director's effect on Nova Scotia's quasi-sovereign interests in petroleum markets and economic activity within the province as "directly affecting" Nova Scotia. Indeed the Court stated that these interests are sufficient to form a "direct interest" under s. 18.1 of the $F C A$. $^{46}$ However, it does not appear that Nova Scotia argued that it should be granted standing as a right on the basis of parens patriae.

However, parens patriac standing for a province to challenge a federal decision was directly addressed in Prince Edward Island v. Canada. ${ }^{47}$ Prince Edward Island issued a statement of claim against the defendants, seeking a series of declarations respecting decisions made pursuant to s. 7 of the Fisheries $A c t^{8}$ including that the Minister:

- breached his public trust obligations;

- failed to comply with his own policies and has taken into account considerations not contemplated by these policies;

- took irrelevant considerations into account;

- failed to act in accordance with the principles of procedural fairness; and

- failed to meet fishers' legitimate expectations.

Canada applied to strike the statement of claim on numerous grounds including that the province had no standing to pursuc the action. The breach of public trust obligations was set out in Prince Edward Island's statement of claim:

The fishery in Canada is a common property resource that is managed by Canada or the Minister, or both, as a trustec, or fiduciary, and for the benefit of all Canadians, as beneficiaries. As such, they are required to comply with all common law obligations that pertain to that role. Those common law responsibilities include the duty to act in good faith, to act in the interests of all bencficiaries and to avoid conflicts of interest, to preserve the fishery, to act prudently, to treat all beneficiaries impartially and with an even hand, and to lumish informution and reasons to persons aflected by his decisions, to Islanders and Canadians generally. 
about the managentent of the fishery. For ease of reference, these obligations will be referred to as the "Public Trust Obligations."

In considering the nature of the tort of "breach of public trust," the motions judge referred to Canadian Forest Products as evidence that Canadian common law recognizes the Crown's right to standing to claim against a party causing damage to the public interest. ${ }^{50}$ Justice Campbell also noted that there is a long-standing recognition that common property and public rights are vested with the Crown and that Henry de Bracton in Bracton on the Laws and Customs of England d $^{\prime \prime}$ recognized this as early as the thirteenth century. Specifically, the Court noted:

If a govemment can exert its right, as guardian of the public interest, to claim against a party causing damage to that public interest, then it would seem that in another case, a beneficiary of the public interest ought to be able to claim against the government for a failure to properly protect the public inlerest. A right gives rise to a corresponding duty. ${ }^{52}$

The motions judge found that the province had standing to seck relief for the federal Crown's breach of duty to act as trustee for the fishery and dismissed Canada's application to strike the statement of claim. On appeal to the Prince Edward Island Supreme Court, Appeal Division, the panel of judges struck the statement of claim on the grounds that $\mathrm{s} .7$ of the $F A$ conveyed an absolute discretion on the Minister to grant licences, and therefore the remaining claim against the Crown disclosed no reasonable cause of action. The Court also ruled that the public trust claim should be heard by the Federal Court and did not address the standing of the province to bring such a claim against the federal Crown. ${ }^{53}$

The Minister's discretion under s. 7 of the $F A$ was also challenged in Federal Court in Numavu Terrisory (AG.) v. Canada (A.G.). The Attorney General of Nunavut applied for judicial review of the shrimp quota allocation made by the Minister of Fisheries and Oceans with respect to the waters near Baffin Island for the year 2003. The Attorney General of Canada asserted that Nunavut's Attorney General lacked standing to bring the application. The Federal Court agreed that Nunavut's Attomey General did not have standing to bring the application as he was not a person directly affected by the allocation. First, Nunavut Territory's legislative jurisdiction was not in conflict with the authority of the Minister to issue fishery licences and to fix quotas. Second, no other interest of the applicant was directly affected by the decision here under review as there was no evidence before the Court that the Government of Nunavut held any interest in a Northern shrimp lishery licence."

The Court also declined to grant public interest standing to Nunavut as there was another reasonable and effective way to bring the Minister's quota allocation decision for judicial review. The judicial review application should have been brought, according to the Court,

Prince Echward /skemd, suprat nolc 47 at para. 6.

thid. al para. 35 .

Trans. by Samuel E. Thorne (Cambridge, Mass.: Belknalp, 1968) at 327.

Prince Edward Islamd, supra note 47 at para. 37.

Canada (A. G.) v. Prince Edhurd lsland. 2006 PESCAD 27, 263 Nild. \& P.E.I.R. 4.

2005 FC 342, 265 F.T.R. 193 [Ninknu].

Ibid. at paras. $40-41$. 
by Nunavut Tunngavik Inc., the representative organization of lnuit in Nunavut who held fishery rights under the Nunawu Land Claims Agreemen Act. ${ }^{56}$ It does not appear that the Attorney General of Nunavut argued that he had standing as a right to protect a quasisovereign interest of Nunavut."

However, such an argument was advanced in Alberta v. Canada (Wheat Board) ${ }^{58}$ In that case, the province argued that in the assignment and management of quotas the respondent was failing to fulfill certain of its statutory obligations under the Canadian Wheat Board Act. ${ }^{39}$ The Canadian Wheat Board (CWB) argued that the province had no standing as it was not "directly affected" by the quotas.

Three bases were advanced for standing on the part of the province: first, as a person or entity "directly affected" by the grain delivery program of the respondent; second, on the basis of public interest; and third, as of right. ${ }^{\text {"N }}$ The Federal Court found that the province was not "directly affected" by the CWB policy and that it was not appropriate to grant the province public interest standing as there were other, more appropriate petitioners to bring such an application - farmers in Alberta.

With respect to its assertion that the province enjoyed standing as a right, the province noted it:

- had long been interested in grain marketing in the province of Alberta;

- had exercised a long-standing regulatory role in relation to the production, supply, delivery, and marketing of agricultural products in the province; and

- had a social and economic interest in maintaining farm operations and the resulting employment in the province. ${ }^{\text {.1 }}$

This, according to the province, demonstrated that the province was "directly affected" or was a proper public interest litigant in much the same way that Nova Scotia was in Uliramar. The Court did not accept that argument and suggested that only farmers were directly affected by CWB quotas. In the alternative, the province argued that it had standing as a right although it did concede that it was not clear whether Canadian courts recognized

S.C. 1993. c. 29.

It is arguable, however, that Nunavul would be granted such standing as it is not a Crown separate from the federal Crown with distinet sovereign interests but rather a creature of federal legislation. As such, the rationale fir such standing outlined, the sovereign riglt of the Crown to standing, infra note 140 , is not present. For more on the constitutional nature of the territorial govemments see: Féderation Francostémoise' 1 . Camada, 2001 FCA 220. [2001] 3 F.C. 641: Penike'll v. Camede (1988). 45 D.L.R. (4th) 108 (B.C.C.A.); Yellowkmife Public Denominatiomal District Education duthority v. Eucher. 2007 NWTSC 15, 283 D.L.R. (4th) 400: Norahwest Territories : Public Service Alliance of Canada, 20001 FCA 162. [2001] 3 F.C. 566.

[1998] 2 F.C. 156 (T.D.) [Canndian Wheat Board].

R.S.C. 1985, c. C.24.

Conadian Wheol Bourd, supra note 58 at para. 28.

Ibid. 
that a provincial Crown had prerogative right to standing for judicial review of federal bodies. In response, the Court stated:

Finally, on standing as of right, it is to be noted that Parliament specilically provided such standing to the Attomey General of Canada. I am not prepared to conclude that failure to grant equivalent standing to the attomeys general of the provinces was a mere oversight. If Parliament had intended to confer such standing it could easily have done so. I am not prepared to read into section 18.1 of the Federal Cours det the words that counsel for the applicant would have me rend in. Nor, in the ibsence of such words, do I fect at liberty to recognize a common law right of standing. ${ }^{\text {h2 }}$

The Court concluded that the applicant province did not have standing to bring an application for judicial review. The Federal Court of Appeal dismissed Alberta's appeal and did not address its arguments that a province should have standing as a right with respect to questions of general importance. ${ }^{63}$

In both Nimavu and Canadian Wheat Board, the fact that the province (or territory) had an interest in the economic well-being of its citizens was not regarded as a direct interest and, in Canadian Wheal Board, the Court characterized such a basis of standing to be an exemption to the general rule outlined in the FCA. As the American cases discussed below . have demonstrated, the better view is that the province's (and perhaps territory's) role as parens patriae, a role long-established at common law, does not create an exception to the normal rules for standing. As provincial Crowns have a special role as parens patriae, they should be subject to different standing requirements than normal litigants. Where it can be demonstrated that a federal body's actions will affect a province's quasi-sovereign interest, this action directly affects the province. As such, there is no need to consider whether public interest standing is applicable or whether an exemption to normal standing requirements has been created by the legislature.

\section{STANDing IN ThE UNited States}

\section{A. Standing to Enforce Public Rights}

As in Canada, in the U.S., a party must show particular harm to be granted standing to request review of government action. This stems from the jurisprudence surrounding art. III, s. 2 of the U.S. Constitution which gives the courts jurisdiction over cases or controversies. ${ }^{\text {(it }}$ American cases have established that standing will be granted where an actual case or controversy exists, meaning three elements are present: first, to be a legally protected

not

lbid. at para. 33.

Alberta v. Camada (Conadian Whear Board) (1998), 234 N.R. 74 (F.C.A.).

The U.S. Constituion, U.S. Const. art.III. \$2. cl. I reads:

The Judicial Power shall extend to all Cases, in Law and liquity, arising under this Constitution, the Laws of the United States, and Treaties made, or which shall be made, under their Authority:-to all Cases aflecting Ambassadors, other public Ministers and Consuls;-to all Cases of admiralty and maritime Jurisdietion;-to Controversies to which the Uniled States shall be a Party;-10 Controversies between two or more States:-between a State and Citizens of another State;-between Citizens of dilferent Stales;-between Citizens of the Same State claiming land under Grants of different States, and between a State, or the Citizens thereof, and foreign States. Citizens or Subjects. 
interest, the plaintiff must have suffered an injury which is (a) concrete and particularized, ${ }^{65}$ and (b) actual or imminent, not conjectural or hypothetical; ${ }^{66}$ second, there must be a causal connection between the injury and the conduct complained of $;^{67}$ and third, it must be likely, as opposed to merely speculative, that the injury will be redressed by a favourable decision. ${ }^{68}$

Specifically, in Bakerv. Carr, ${ }^{69}$ the U.S. Supreme Court stated that the essence of standing was whether the petitioners have "such a personal stake in the outcome of the controversy as to assure that concrete adverseness which sharpens the presentation of issues upon which the court so largely depends for illumination." 70

The U.S. Supreme Court discussed standing at length in Lujan (Secretary of the Interior) v. Defenders of Wildlife. ${ }^{71}$ In that case, the petitioners challenged a decision made pursuant to the Endangered Species Act of 1973. ${ }^{72}$ The Secretaries of the Interior and Commerce initially promulgated a joint regulation extending the requirements of the ESA to U.S. government actions taken in foreign nations, but a subsequent rule limited the section's geographic scope to the U.S. and the high scas. The petitioners, a non-profit private sector organization, sought a declaratory judgment that the new regulation erred as to the geographic scope of the ESA and requested an order requiring the Secretaries to promulgate a new rule restoring the initial interpretation.

The Court concluded that the respondents lacked standing to seek judicial review of the rule. Writing for the Court, Scalia J. found that the petitioners did not demonstrate that they suffered an injury specific to them. None of the petitioners would be directly affected apart from the members' special interest in the subject. ${ }^{73}$

\section{B. Public Interest Standing}

Like Canadian courts, American courts have an exception to the general rule that nonjusticiable cases - those that raise no controversy or injury - are moot. American courts may exercise their discretion to grant a public interest exemption to the mootness doctrine where:

- the disputed issues are capable of repetition;

- the mootness doctrine, if applied, may cause review of the issues to be repeatedly circumvented; and

Wharh v. Seldit, 422 U.S. 490 at 508 (1975): Sierra Chb v. Morton (Secretary of the Imerior), 405 U.S. 727 at 740-41. n. 16 (1972).

to Los Angeles (Ciity of v. Lyems, 461 U.S. 95 at 102 (1983).

n7 Simon (Sccretary of the Treesury) v. Fastern Kennucky Welfore Rights Organization, 426 U.S. 26 at 41 . 42 (1976).

as Ibid. at 38

(4) 369 U.S. $186(1961)$.

i) thid. at 204.

$\because \quad 504$ U.S. 555 (1992) [Lujan].

$\because \quad 16$ U.S.C. $\$ 1531(1973)[E S A]$.

$" \quad L$ Lujom, supra note 71 at 563 . 
- the issues presented are so important to the public interest as to justify overriding the mootness doctrine. ${ }^{74}$

\section{Parens Patriae Standing to Protect Public Rights}

Parens patriae is an increasingly important basis for standing in American courts for states seeking to protect their quasi-sovereign interests, such as those relating to its citizens' health or safety and even economic well-being. Courts in the U.S. have also recognized the interest of a state in procuring the protection of federal legislation to be a quasi-sovereign interest.

In the U.S., parens patriae has a long history as a basis for states to seek equitable relief or damages from private parties. Less commonly, governments will also rely on parens patriae standing to petition courts for prerogative writs restraining or ordering action from the federal government or another state. Standing may be granted where a state is seeking to protect a sovereign or quasi-sovereign interest.

That a parens patriae action could rest upon the articulation of a quasi-sovereign interest was first recognized by the U.S. Supreme Court in Louisiana v. Texas. ${ }^{\text {In }}$ In that case, Louisiana unsuccessfully sought to enjoin a quarantine maintained by Texas officials, which had the effect of limiting trade between Texas and the Port of New Orleans. The Court labelled Louisiana's interest in the litigation as that of parens patriae, and went on to describe that interest by distinguishing it from the sovereign and proprietary interests of the state:

Inasmuch as the vindication of the freedom of interstate commerce is not commilted to the State of Louisiana, and that State is not engaged in sucls commerec, the cause of action must be regarded not as involving any infringement of the powers of the State of Louisiana, or any special injury to her property, but as asserting that the State is entitled to seek relief in this way because the matters complained of affect her citizens at large. ${ }^{76}$

Further cases followed in which states successfully sought to represent the interests of their citizens in enjoining public nuisances and protecting economic well-being. ${ }^{77}$ The public nuisance and economic well-being interests were brought together in Georgia v. Pennsylvania Railroad. ${ }^{78}$ In that case, Georgia alleged that some 20 railroads had conspired to fix freight rates in a manner that discriminated against Georgia shippers in violation of the federal antitrust laws. In discussing Georgia's standing, the Court stated:

Southern Pacific Terminal v. Imerstate Commerce Commission, 219 U.S. 498 at 514-16 (1911): Moore v. Ogihvie (Governor of Illinois), 394 U.S. 814 at 816 (1969); Carroll t. Presidem and Commissioners of Princess Anne, 393 U.S. 175 at $178-79$ (1968); Unifed States v. W.T. Grum Co., 345 U.S. 629 at 63233 (1953); Roe v. Wade (District Atromey of Dallas Comm!), 410 U.S. 113 at $124-25$ (1973).

lbid. at 19.

North Dakota v. Mimmesota, 263 U.S. 365 (1923); Wyoming v: Colorado, 259 U.S. 419 (1922); New York v. New Jersey, 256 U.S. 296 (1921); Kansas y: Colorato. 206 U.S. 46 (1907): Georgia v: Tenmessee Copper, 206 U.S. 230(1907) [Tennessee Copper]; Kansas v. Colorado, 185 U.S. 125(1902); Missouri v. Mllinois, 180 U.S. 208 (1901) [Missouri]. 
If the allegations of the bill are taken us true, the economy of Georgia and the welfare of her citizens lave scriously suffered as the result of this alleged conspiracy... [Trade barriers] may cause a blight no less serious than the spread of noxious gas over the land or the deposit of sewage in the streams. They may affect the prosperity and welfare of a State as profoundly as any diversion of waters from the rivers.... Georgia as a representative of the public is complaining of a wrong which, if proven, limits the oppontunities of her people, shackles her industries, retards her development, and relegates her to an inferior economic position among her sister States. These are matters of grave public concern in which Georgia has an interest apart from that of particular individuals who may be affected. ${ }^{74}$

The U.S. Supreme Court reviewed the history of parens patriae, examined the nature of parens patriae standing, and considered which quasi-sovereign interests support standing on the parens patriae basis in Alfred L. Snapp. ${ }^{\text {.0 }}$ In that case, Puerto Rico sought to sue in its capacity as parens patriae against a number of individuals and companies for discrimination against Puerto Rican farm workers. Specifically, Puerto Rico alleged that the companies were acting in violation of both the Wagner-Peyser $A c r^{81}$ and the Immigration and Nationality Act of $1952 .{ }^{82}$ The purposes of this statutory scheme was to give American workers, including citizens of Puerto Rico, a preference over temporary foreign workers for jobs that become available in the U.S. To establish parens patriae standing, Puerto Rico alleged that the violation of the federal scheme deprived

"the Commonwealth of Puerto Rico of its right to effectively participate in the benefits of the Federal Employment Service System of which it is a part" and thereby caused irreparable injury to the Commonwealth's efforts "to promote opportunities for profitable employment for Puerto Rican laborers and to reduce unemployment in the Commonwealth.. ${ }^{.83}$

The Court stated that the Commonwealth's standing was not based on proprietary interests or sovereign interests. Puerto Rico's allegations that the defendants discriminated against Puerto Ricans in favour of foreign labourers fell within the Commonwealth's quasi-sovereign interest relating to the general well-being of its citizens. ${ }^{84}$ The Court found that Puerto Rico had parens patriae standing to pursue its residents' interests in the Commonwealth's full and equal participation in the federal employment service scheme established by the laws involved here. ${ }^{85}$ However, the Court characterized Puerto Rico's interest as a "quasisovereign" interest. Such interests, according to the Court, stand apart from sovereign interests, proprietary interests, or private interests. They consist of a set of interests that the state has in the well-being of its populace. However, a quasi-sovereign interest must be sufficiently concrete to create an actual controversy between the state and the defendant in order to be considered a matter suitable for review by the Court under art. Ill of the U.S. Constitution. ${ }^{86}$ 
The Court made the following conclusions regarding the case law involving parens patriae actions. Two requirements must be met: first, "[i]n order to maintain such an action, the State must articulate an interest apart from the interests of particular private parties, i.e., the State must be more than a nominal party. [Second, t] interest. ${ }^{187}$ With respect to the second requirement, the Court stated that the there were two types of quasi-sovereign interests (although the categories were not closed):

First, a Stale has a quasi-sovereign interest in the health and well-being - both physical and economic of its residents in general. Second, a State has a quasi-sovercign interest in not being discriminatorily denied its rightful status within the federal system. ${ }^{88}$

For the first type of quasi-sovereign interest, the Court commented that, when determining whether an alleged injury to the health and welfare of its citizens suffices to give the state standing to sue as parens patriae, one should ask whether the injury is one that the state, if it could, would likely attempt to address through its own sovereign law-making powers. ${ }^{89}$ For the second form of quasi-sovereign interest, the Court noted that a state has a right to ensure that the state and its residents are not excluded from the benefits that are to flow from participation in the federal system.

Therefore, there were two significant developments in the American courts' articulation of what constitutes a quasi-sovereign interest. Threats to a state's economic well-being or its citizens' health or welfare from a public nuisance were recognized as quasi-sovereign interests which could be enjoined and where damages could be sought. Additionally, with Alfred L. Snapp, the U.S. Supreme Court clarified another type of quasi-sovereign interest - the right for a state's citizens to obtain the benefits of federal legislation.

\section{State Standing to Seek Judicial Review OF FEDERAL ADMINISTRATIVE ACTION}

In the U.S. Supreme Court cases discussed above, states were primarily seeking equitable relief or damages from other states or individuals for actions which undermined their quasisovereign interests. However, the ability of a state to seek judicial review of federal administrative action was not addressed comprehensively by the U.S. Supreme Court until Massachusetts. ${ }^{91}$ In that case, a group of states, local governments, and private organizations alleged in a petition for certiorari that the Environmental Protection Agency (EPA) had failed to fulfill its responsibilities under the Amendments to Clean $\mathrm{Air} \mathrm{Acr}^{92}$ to regulate the emissions of four greenhouse gases.

Ibid. at 607 .

Ibid.

Ibid.

thid. at 608.

Supra note 35.

42 U.S.C. $\$ 7521(1990)[C A A]$. 
On 8 September 2003, the EPA entered an order denying a rule-making petition. ${ }^{93}$ The order was in response to a petition filed by 19 private organizations asking the EPA to regulate greenhouse gas emissions from new motor vehicles under s. 202 of the $C A A .^{94}$

The petitioners sought review of the EPA's order in the U.S. Court of Appeals. Two judges agreed that the EPA properly used its discretion under s. 202(a)(1) in denying the petition. ${ }^{95}$ In his decision, Randolph J. concluded that the EPA was reasonable in basing its decision on scientific uncertainty as well as on other policy factors. ${ }^{96}$ Justice Sentelle found that the petitioners lacked standing as their application was based on harm to humanity at large rather than particular injuries to the petitioners. ${ }^{97}$ In support of this, Sentelle J. cited the U.S. Supreme Court reasons in Lujan.

The third member of the panel, Tatel J., dissented and found that Massachusetts had satisfied each element of standing: injury, causation, and redressability. ${ }^{98}$ Justice Tatel found that the EPA's failure to curb greenhouse gas emissions contributed to the sea level changes that threatened Massachusetts' coastal property. ${ }^{99}$ With respect to redressability, Tatel J. found that the petitioners had established through expert evidence that achievable reductions in emissions of greenhouse gases from American motor vehicles would "delay and moderate many of the adverse impacts of global warming." 100 Justice Tatel concluded that the statute provided EPA with authority to regulate greenhouse gas emissions and its refusal to exercise that authority was not justified. ${ }^{101}$

The petitioners appealed to the U.S. Supreme Court. With respect to standing, the U.S. Supreme Court found, like Tatel J. at the Court of Appeal, that the special position and interest of Massachusetts were sufficient to satisfy the elements of standing. ${ }^{102}$ More controversially, however, the Court distinguished the applicants' petition in Lujan from Massachusetts' position, noting that it was of considerable relevance that the party seeking review was a sovereign state and not, as it was in Lujan, a private individual. ${ }^{103}$

To justify its treatment of states in a different manner compared to ordinary litigants, the Court relied principally on Holmes J.'s opinion in Tennessee Copper, ${ }^{104}$ a case in which

68 Fed. Reg. 52922 (2003).

Section $7521(a)(1)$ of the $C A A$, supra note 92 reads:

The Administrator shall by regulation prescribe (and from time to time revise) in accordance with the provisions of this section, standards applicable to the emission of any air pollutant from any class or classes of new motor vehicles or new motor vchiclc engines, which in his judgment cause, or contribute to, air pollution which may reasonably be anticipated to endanger public health or welfare.

Massachusetts v. Environmental Protection Agency, 415 t.3d 50 al 58 (D.C. Cir. 2005).

ibid.

Bbid. al 60.

lbid. at 64 .

Ibid. al 65 .

Ibid.

Ibid. at 67-82.

Massachusetts, supra note 35 at 15 of the majority judgment.

lbid.

Sipra nole 77. 
Georgia sought to protect its citizens from air pollution originating outside its borders. Justice Holmes stated:

\begin{abstract}
The case has been argued largely as if it were one between two private parties; but it is not. The very elements that would be relied upon in a suit between fellow-citizens as a ground for equitable relict are wanting here. The State owns very little of the lerritory alleged to be aflected, and the damage to it capable: of estimate in money, possibly, at least, is small. This is a suil by a Stale for an injury to it in its capacity of quasi-sovereign. In that capacity the State has an interest independent of and hehind the titles of its citizens, in all the earth and air within its domain. It has the last word as lo whether its mountains slall be stripped of their forests and its inhabitants shall breathe pure air. ${ }^{105}$
\end{abstract}

The Court went on to explain that when a state enters the Union, it surrenders certain sovereign prerogatives. These sovereign prerogatives are now lodged with the U.S. federal government. The U.S. Congress had ordered the EPA to protect Massachusetts (among other states) by prescribing standards applicable to the "emission of any air pollutant from any class or classes of new motor vehicies or new motor vehicle engines, which in [the Administrator's] judgment cause, or contribute to, air pollution which may reasonably be anticipated to endanger public health or welfare." ${ }^{106}$ Accordingly, the Court reasoned that Massachusetts was entitled to special consideration in a standing analysis.

With respect to injury, the Court stated that: "[t]he harms associated with climate change are serious and well recognized." 107 The Court stated that the petitioners had identified a number of environmental changes that have already inflicted significant harms, including the global retreat of mountain glaciers, reduction in snow-cover, earlier spring melting of rivers and lakes, and the accelerated rate of rise of sea levels during the twenticth century. Specifically, the Court noted that rising seas had already reduced Massachusetts' coastal land. ${ }^{108}$ The Court concluded that, at a minimum, the EPA's refusal to regulate such emissions contributed to Massachusetts' injuries. ${ }^{10 \%}$

Finally, with respect to redressability, the Court stated that the petitioners need only show that a realistic possibility exists that the relief they sought would mitigate global climate change and remedy their injuries. "' Given that a reduction in domestic emissions would slow the pace of increases in global emissions, regardless of what happens elsewhere, the Court found that Massachusetts met this test. "' The Court concluded that

li]n sum-at least according to petitioners' uncontested alfidavits-the rise in sea levels associated with global warming has alteady harmed and will continue to harm Massachusetls. The risk of catastrophic harm. though remote, is nevertheless real. That risk would be reduced to some extent if petitioners received the 
relief they seck. We therefore hold that petitioners have standing to challenge the EPA's denial of their rulemaking petition. $1 / 2$

The Court ultimately concluded that the EPA had the authority and was obligated to regulate emissions of greenhouse gases from new motor vehicles under the $C A A .^{113}$ Specifically, the Court noted that the $C A A$ provides that the EPA shall prescribe standards applicable to the emission of air pollutants from motor vehicles. ${ }^{1 / 4}$ The EPA offered no reasoned explanation for its refusal to decide whether greenhouse gases cause or contribute to climate change. ${ }^{115}$

Chief Justice Roberts together with Scalia, Thomas, and Alito JJ., wrote dissenting reasons. First, the minority rejected the petition as non-justiciable. Citing Lujan and DaimlerChrysler Corp. v. Cuno, ${ }^{116}$ Roberts C.J. found that the dispute was not a proper "case or controversy," as the terms have been interpreted under art. 111 of the U.S. Constitution, and was more properly a matter for the legislative and executive branches to address. ${ }^{17}$

Second, Roberts C.J. found there was no petitioner with standing 10 sue. ${ }^{118}$ In this regard, the dissent found that the majority "changed the rules" regarding standing for states to seek judicial review. ${ }^{119}$ Chief Justice Roberts argued there was no basis for relaxing art. IIJ's standing requirements because the asserted injuries were pressed by a state. Indeed, Roberts C.J. stated that any support for special treatment was "conspicuously absent from the Court's opinion." ${ }^{20}$ Chief Justice Roberts conceded that Tennessee Copper drew a distinction between a state and private litigants, but solely with respect to available remedies and not for art. Ill standing. ${ }^{121}$ He pointed out that the Court in Tennessee Copper merely explained that while a complaining private litigant would have to accept a legal remedy - one "for pay" - the state was entitled to equitable relief. ${ }^{122} \mathrm{He}$ did not find that a state could show standing where a private party could not in Temessee Copper. Nor, asserted Roberts C.J., was such special treatment supported by the statute. ${ }^{123}$

Finally, Roberts C.J. argued that the Court overlooked the fact that the jurisprudence has held that while a state might assert a quasi-sovereign right as parens patriae for the protection of its citizens, it cannot assert such a right in respect of its relations with the federal government. In that field, it is the U.S., and not the state, which has that right. ${ }^{14}$ Indeed, he

11:

113

114

IIS

116

117

IIX

119

121

121

12

123

124

Ibid.

Ibid. at 26 of the majority judgment.

Ibid. at 25 of the majority judgment.

Ibid. at 32 of the majority judgment.

547 U.S. $332(2006)$ at 341.

Massachuselts, supra note 35 at 2 of the dissenting judgment.

thisl.

lbid.

this.

thisd.

Termessee Copper, suppra note 77 at 237-238.

Massachusetts, supra note 35 at 4 of the dissenting judgment.

Ibid. at $S$ of the dissenting judgment, citing Mussuchusetss v. Mellon (Secretary of the Treasmy\%, 262

U.S. 447 at $485-86$ (1923) [Mellon, Footnotes omitled] where the Court staled:

It cannot be conceded that a State, as purens putriae, may institute judicial proceddings to protect citizens of the United States from the operation of the statutes thereof. While the State, under some 
suggested that Alfred $L$. Snapp specifically stated that a state does not have standing as parens patriae to bring an action against the federal government. ${ }^{125}$

Justice Stevens, writing for the majority, answered the Chief Justice's criticism in a footnote to the Court's opinion. ${ }^{126}$ Justice Stevens noted Mellon itself disavowed any such reading. Instead, Mellom stands for the proposition that a state cannot use the courts to protect its citizens from the operation of federal statutes. ${ }^{127}$ However, in Pennsylvania Railroad, the Court noted that there is a critical difference between allowing a state "to protect her citizens from the operation of federal statules" and allowing a state to assert its rights under federal law. ${ }^{128}$ Massachusetts did not dispute that the $C A A$ applies to its citizens; rather, it sought to assert its rights under the $C A A^{129}$

Following the Massachusetts decision, state parens patriae standing to seek judicial review of a federal decision may be granted to protect a quasi-sovereign interest. The elements of the right to this type of standing can be summarized as:

(1) A state has special status to seck remedies where a quasi-sovereign interest is being adversely affected even if there is no direct injury to the state but a decision affects its citizens' economic or physical health or welfare;

(2) The injurious, or potentially injurious, effect must be concrete and imminent and capable of redress by a court;

(3) Where a state's quasi-sovereign interest is adversely affected by a federal government decision, parens patriae standing may be granted; and

(4) The relief requested cannot be such that the state is seeking to exempt its citizens or territory from the application of federal law but rather seeking to extend the protection of the government law to its quasi-sovereign interests.

As noted above, the main clarification Alfred L. Snapp brought to parens patriae standing was that a state may bring an action to ensure that its citizens enjoy the benefits of federal legislative schemes. A state, because it has given up legislative jurisdiction in certain realms, has a quasi-sovereign interest in ensuring that legislation enacted by the federal government applies to its state on an equitable basis. Massachuserts confirmed that this special status to seek remedies in a court extends to judicial review of federal public bodies.

circumstances, may sue in that capacity for the protection of its citizens, it is no part of its duty or power to enforee their rights in respect of their relations with the Federal Govemment. 


\title{
V. THE Proper Role of the \\ Parens Patriae Doctrine in Canadian Courts
}

\section{A. The Role of the Courts in a Federal State}

In international law, it is axiomatic that sovereignty justifies state action within the state's territory (subject, of course, to internationally accepted norms). ${ }^{130}$ It is also accepted that a sovereign state may act to protect itself from threats to its legitimate sovereign interests outside its territory. ${ }^{131}$

A federation is normally understood as a group of sovereign states that voluntarily hand over part of their sovereignty to a central government which is subsequently endowed with agreed upon legislative jurisdiction within the bounds of the federation. Chief Justice Marshall stated in Gibbons v. Ogden that prior to the formation of the federation, the states

\begin{abstract}
were sovereign, were completely independent, and were connected with each other only by a league. This is true. But when these allied sovereigns converted their league into a government, when they converted their congress of ambassadors. deputed to deliberale on their conmon concerns, and to recommend measures of gentral utility, into a legislature, empowered to enact laws on the most interesting subjects, the whole character in which the states appear, underwent a changc, the extent of which must be determined by a fair consideration of the instrument by which that change was efrected. ${ }^{132}$
\end{abstract}

The Supreme Court of Canada made this point particularly clear in the Canadian context:

The federal character of the Canadian Constitulion was recognized in innumerable judicial pronouncements. We will quole only one, that of Lord Watson in Liquidarors of the Maritime Bank of Canoda v. ReceiverGeneral of New Brimswick, supra, at pp. 441-42:

\begin{abstract}
The object of the Act was neither to weld the provinces into one, nor to subordinate provincial governments to a central authority, but to create a federal government in which they should all be represented, entrusted with the exclusive administration of affairs in which they had a common interest, tach province retaining its independence and autonomy. ${ }^{133}$
\end{abstract}

Typically where provincial or state legislative jurisdiction ends and federal jurisdiction begins is set out in a federal constitution. Questions regarding the interpretation of legislative jurisdiction between the sub-units and federal government are resolved judicially. The seminal case regarding the U.S. Supreme Court's jurisdiction to review government legislation on federal grounds is Gibbons. ${ }^{134}$ The Judicial Council of the Privy Council also assumed jurisdiction to review provincial and federal legislation for compliance with the

J.L. Brierly, The Law of Nations: An Introduction to the Imernational Lan of Peace, Gth ed. by Sir Humphrey Waldock (Oxford: Clarendon Press, 1963) at 7-16.

Sece e.g. Trail Smelter Arbitration (United States v. Canada) (1938, 1941). 3 United Nations Reports of International Arbitral Awards 1905 at 1965.

22 U.S. (9 Wheal.) ] at 187 (1824) [Gibbons].

Reference Re Resolution to Amend the Constitution. [1981] I S.C.R. 753 at 905; Liquidators of the Maritime Bumk of Canada $v$. New Brunswick (Receiver General), [1892] 1 A.C. 437 at $441-42$ (P.C.).

Supra note 132. 
enumeration of powers in The Constitution Act, $1867^{135}$ in Citizens Insturance v. Parsons. ${ }^{136}$ Peter W. Hogg summarizes the role of the courts in a federal constitutional state: "The fact is that disputes as to the distribution of legislative power are inevitable within a federation, and ultimately there is no body with power to decide them other than the courts."137

As discussed, in the U.S., standing may be granted to a state govermment to seek judicial review of a federal decision if it is a quasi-sovereign right. The courts recognize that such standing flows naturally from the fact that a federation is a voluntary union of sovereign states.

For example, in Missouri, ${ }^{138}$ Missouri sought an injunction to prevent the defendants from discharging sewage in such a way as to pollute the Mississippi River in Missouri. The U.S. Supreme Court relied upon an analogy to independent countries in order to delineate those interests that a state could pursue in federal court as parens patriae:

It is true that no question of boundary is involved, nor of direct property rights belonging lo the complainant

State. But it must surcly be conceded that, if the health and comfort of the inhabitants of a State are threalened, the State is the proper party to represent and defend them. If Missouri were an independent and sovereign State all must admit that she could seek a remedy by negotiation, and, that failing, by force. Diplomatic powers and the right to make war having been surrendered to the general government, it was to be expected that upon the latter would be devolved the duty of providing a remedy and that remedy. we think, is found in the constitutional provisions we are considering. 139

Using an analysis similar to Missouri, the U.S. Supreme Court explained in Massachtusetss that when a state enters the Union, it surrenders certain sovereign prerogatives. For example, Massachusetts "cannot invade Rhode Island to force reductions in greenhouse gas emissions, it cannot negotiate an emissions treaty with China or India, and in some circumstances the exercise of its police powers to reduce in-state motor vehicle emissions might well be preempted." ${ }^{.10}$ Since these sovereign prerogatives are now lodged in the U.S. Federal Government, the Court reasoned that states are entitled to special consideration in a standing analysis.

In a federation, regional governments are autonomous sovereign entities which have decided to form a central government with agreed upon legislative jurisdiction resting with the wider federal state. Since the regional governments do not enjoy full legislative or geographic sovereignty over the federal state as a whole; and the courts are the final arbiter of the limits of the geographic and legislative jurisdiction in a federation, regional governments deserve special status with respect to standing. Although this rationale is applicable to both Canadian and American federalism, the right to special rights to standing

(U.K.) 30 \& 31 Vict., c. 3, reprinted in R.S.C. 1985, App. Jl. No. 5.

(1881), 7 App. Cas. 96 (P.C.): see also Peter W. Hlogg. Constimtional l.aw of Canada, looseleaf ed. (Scarborough, Ont.: Thumson Carswell, 1997) at 5-23.

Massachuselts, supra note 35 at 16 of the majority judgment. 
for states has been recognized and elucidated much more comprehensively by the American courts than by Canadian courts.

\section{B. The Scope of the Crown's Parens Patriae STANDing to Protect QUASI-SOvereign RightS}

The potential scope of the common law right to standing has been demonstrated by Australian courts that have interpreted the principle to give states special status to challenge the validity of Commonwealth laws. ${ }^{1+1}$ The High Court of Australia, as early as 1935 stated:

It must now be taken as established that the Attomey-General of a State of the Commonwealth has a sufficient title to invoke the provision of the Constitution for the purpose of challenging the validity of Commonwealth legislation which extends to, and operates within, the State whose interests he represents. ${ }^{142}$

Justice Laskin commented in Thorson on the role of the provincial Attorney General to bring actions to challenge the constitutional validity of federal laws:

There is Australian authority to support a declaralory action by a State Attorney General to challenge the validity of Commonwealth legislation where that legislation amounts to an invasion of State legislutive power: see Altorney' General for Victoria v. The Commonucalth. This, and other like cases cited therein, represent an adaptation to Australian federalism of the English position of the Attomey General as the guardian of public rights, those rights being the rights of the citizens of the State whom the State Altomey General represents. On the other hand, authority in the United States is to the contrary. In Massachuserts v. Mellon, a companion case to Frothingham v. Mellon considered below, the Supreme Court of the United States said this on the point (at p. 485):

It cannot be conceded that a State, as parens patrice, may institute judicial proceedings to protect citizens of the United States from the operation of the statules thereof... While the State, under some circumstances, may sue in that eapacily for the protection of its citizens ... it is no part of its duty or power to enforce their rights in respect of their relations with the Federal Government. ${ }^{143}$

The potential scope of the Crown's right to pursue civil remedies for breaches of its quasisovereign interests as parens patriac has not been extensively explored. ${ }^{144}$ The scope of the Crown's ability to pursue judicial review of administrative action affecting its quasisovereign interests is even less developed. At a minimum, we can conclude that this common law right does not include constitutional review of the validity of legislation. Provincial Attorneys General have the right to appear wherever the constitutionality of an act of Parliament or an act of a provincial legislature arises in Federal Court proceedings ${ }^{145}$ and 
constitutional questions legislation exists in all provinces and federally. ${ }^{\text {th }}$ This legislative remedy guarantees standing where a provincial Attorney General questions the constitutionality of federal legislation. Therefore, the common law doctrine of parens patriae standing for provinces is limited to standing for judicial review of federal bodies in Canada. Therefore, although the extent of parens patriae standing in Canadian common law is clear, it is likely closer to the narrow form outlined by American courts.

\section{Process: Is Legisi,ative. Change Needed?}

It is likely that this issue will come before Canadian courts again, in particular the Federal Court of Canada. Where provinces do come forward with petitions for review of federal administrative action based on a quasi-sovereign interest, the province should be regarded as a petitioner "directly affected" by the federal public body's action. It should not need to establish that its standing is in the public interest and that there is no other potential petitioner that is more directly affected, as the courts found in Canadian Whear Board and Nunawu. Canadian Fores/ Products seems to indicate that provinces have standing at common law to seek equitable and legal remedies wherever there is a threat to the health and well-being, both physical and economic, of its residents in general. ${ }^{147}$

This common law doctrine has not been specifically displaced by the wording of the $F C A^{148}$ which gives standing to the federal Attomey General as well as anyone "directly affected" by federal administrative action to seek judicial review of federal administrative action. It is an accepted rule of interpretation that the common law can only be ousted by statute with specific language. ${ }^{1+9}$ Additionally, the courts have found that s. 18.1 of the $F C A$ is broad enough to encompass applicants who are not directly affected when they meet the test for public interest standing. ${ }^{150} A$ fortiori, it can be concluded that where a provincial Crown's quasi-sovereign interest is affected by federal administrative action, the test for standing under $\mathbf{s .} 18.1$ is satisfied.

Indeed, without mentioning the parens patriae doctrine, the Federal Court in Ultramar noted that Nova Scotia's interest in the federal regulation of competition, which affected the general economic well-being of the province, could not be taken as anything other than a genuine, important public interest which only the province can represent. ${ }^{151}$ Accordingly, courts, including the Federal Court of Canada, have the jurisdiction to grant standing and provincial Crowns have the right to standing where a quasi-sovereign interest is threatened.

Sce e.g. Constitutional Qwestions Act, R.S.N.S. 1989. c. 89: Comstimtional Questions Act, R.S.M. 1987, c.C180, C.C.S.M. c. C180; Constitutional Questions Act. R.S.S. 1978, c. C-29: Constitutional Question Act, R.S.B.C. 1996, c. 68; Supremo Comr Act, R.S.C. 1985, c. S-26, s. 53. Canadian Forest Products, stupra note 22: Jones, supra note 7 at 150.

Ruth Sullivan, Sullivan and Driectger on the Construction of Statudes, 4th ed. (Markham: Butlerworths. 2002) at 341 . 


\section{Conclusion}

The question this article seeks to address is both prescriptive and descriptive. To be sure, the state of the law in the U.S. with respect to state standing to protect quasi-sovereign interests is not entirely settled. The polarization between the slim majority and the minority in Massachusetts was stark but consistent with the prevailing ideological divide within the U.S. Supreme Court. ${ }^{152}$ Indeed, the decision has already been criticized as stretching the law of standing beyond any reasonable interpretation of art. III of the U.S. Constitution. ${ }^{153}$ Nevertheless, descriptively, we can sec that the development of the parens patriae doctrine in the U.S. has reached a certain quod erat demonstrandum that has not been achieved in Canada.

In the U.S., as in Canada, the federation is made up of sovereign regional govemments and a central government that share legislative jurisdiction. As such, the traditional and unquestioned right of the Attorney General in English common law to assert a purely public right or interest in its role as parens patriae by the institution of court proceedings is complicated by the existence of several Attorneys General within the same federation. The Attorney General's standing in a federation has been partially addressed by recognizing a limited role of the Crown to institute proceedings against private individuals seeking injunctions, damages, and other appropriate remedies to protect public rights. This is generally recognized by courts in both Canada and the U.S. Canadian legislation also grants provincial and federal governments standing to bring constitutional questions to the courts as a right. However, where public rights are threatened by federal and provincial Crowns, there is no means of addressing the threat or damage unless the Crown can show a direct interest.

In the U.S., however, there is recognition that a state has a quasi-sovereign interest to standing where the well-being of its citizens is threatened or it is being denied its rightful status within the federal system. This is a basis of standing that has not been recognized by Canadian courts. Courts in Canada cannot fully discharge their constitutional mandate to be the final arbiter of federalism unless provinces have access to similar remedies.

19: Jonathan H. Adler, "Warming Up to Climate Change Litigation," online: (2007) 93 Va. L. Rev. In Brief $63<$ http: $/$ virginialawreview.org/inbricf.php?s=inbric $\& p=2007 / 05 / 21 /$ adler $>$. 